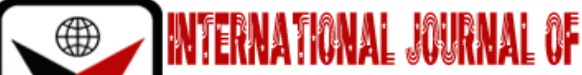

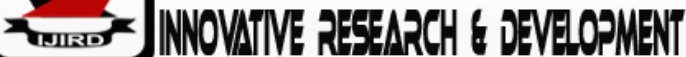

ISSN 2278-0211 (Online)

\section{Growth Performance of African Giant Land Snails (Archachatinamarginata) to Graded Levels of Poultry Droppings as a Replacement for Palm Kernel Cake in the Diet}

Ojomu Adeniyi Andrew
Vice Principal, Department of Vocational and Technical Education,
Goldmark Education Academy, Ugbowo, Benin City, Edo State, Nigeria
Okwo, Chnyere R.
Assistant Lecturer, Department of Agricultural Education,
University of Nigeria Nsukka, Enugu State, Nigeria
Okoruwa Jane Idiaghe
Principal, Department of Vocational and Technical Education,
Ekosodin Secondary School, Ekosodin, Benin City, Edo State, Nigeria
Adiagwai, Fidelia
Assistant Registrar, Department of Science,
Ojo, Faith Uyiosa
The West African Examinations Council, Ijaiye Road Ogba, Ikeja, Lagos State, Nigeria
Teacher, Department of Vocational and Technical Education,
Baptist High School, Benin City, Edo State, Nigeria

\begin{abstract}
:
The study was conducted to determine theGrowth Performance of African Giant Land Snails (Archachatinamarginata) to Graded Levels of Poultry Droppings as a Replacement for Palm Kernel Cake in the Diet. The study determined increase in length, circumference and weight gain of snails. The study was carried out in Benin City, Edo State, South-South Nigeria. A true experimental research design was used for the study. Population for the study was 300 young snails which were bought from Ugbogui Market in Benin City near Okada Town while the sample size of 90 snails was used for the study. The snails were certified by experts before the sample size of 90 was selected. Three research questions and three null hypotheses guided the study. Data was collected on increase in length and circumference of experimental snails and weight gain of the experimental snails. Data on length, circumference and weight gain were collected weekly during the experiment. The length and circumference of the experimental snails were measured using measuring tape while the weight gain was measured using a digital weighing balance. Mean and Standard deviation were used to answer the research questions while one-way Analysis of Variance (ANOVA) was used to analyze and test the null hypotheses. The findings revealed that snails in treatment with diets 2 and 3 containing $25 \%$ and $50 \%$ poultry droppings showed the highest increase in circumference and length/weight gain respectively among others. The study recommended that poultry droppings should be fed to snails at 25\% and 50\% levels of replacement for palm kernel cake in the diet among others.
\end{abstract}

Keywords: African giant land snails, weight gain, length, circumference, poultry droppings, palm kernel cake

\section{Introduction}

The usual practice of picking snails from the bush and forest is no longer trending. This is due to the fact that the natural habitat for snails which is the bush or forest have been lost to various human activities like bush burning, farming, building of roads amongst others; this situation has led to snail domestication. In the view of Cobbinah (2008), snails have been described as invertebrate animals which belong to a phylum called mollusca with shell. Archachatinamarginata which is the African giant land snail belongs to a family called Achatinidaewhich originates from Western, Eastern, and Southern Africa. Snails mostly are found in the forest of tropical countries while some may be found in grassland and they are of different species in the forest.

Different species of snails that are found both in temperate regions and tropical Africa have been identified by Ifediba (2010) as Helix aspersa, Helix pomatia, Helix lucorum, Helix cibeta, Iberusalonensis, Otala-puntala, Achatina civet, Achatinafulica, Archachatinamarginata, Archachatinaventricosa, Archachatinadegneri, Limicolaria species amongst others. Ifediba (2010) described the African land giant snails as being fleshy, highly prolific, with high adaptability and can survive 
easily. These unique characteristics of African giant land snailhave made its rearing in Nigeria and other parts of the world very possible. Ifediba (2010) also highlighted the importance of snail farming which include source of animal proteins and medicinal usefulness.

Snail farming helps to complement animal protein supply in any part of the world. Okereke-Ejiogu, Ogueri and Umnakwe (2016) have opined that snail farming among the rural dwellers who are unable to afford other sources of animal proteins should be encouraged while Ajayi in Okonta (2012) reported that snail meat is low in lipid and saturated fatty acids which makes it good and fit for consumption by hypertensive patients and other people with poor health conditions who may not want to eat fatty foods. Snails also have some medicinal values and usefulness apart from being good source of animal proteins. Ayodele and Ashimolowo in Okereke-Ejiogu (2016) reported that snail mucus is used by nursing mothers among the Yoruba ethnic group in Western part of Nigeria to treat wounds in the umbilical cord. Akannusi in Cobbinah (2008) corroborated this by reporting that the mucus is used to treat heart attack, cardiac arrest, hypertension, stroke, high blood pressure by the Igbos in Eastern part of Nigeria. Its calcium content is also helpful in building strong bones in human body especially the little children. Snail meat has also been reported by Dada, Abu, Okeowo and Badmus in Ugwuowo (2009) to be highly rich in lysine, leucine, isoleucine, phenylalanine, arginine, tryptophan, iron, calcium, phosphorus amongst others. The benefits that can be gotten from snail coupled with its extinction from the bush and forest had led to its farming or domestication.

For Nigerian farmers to ensure snails availability all year round, Ifediba, (2010) had opined that snail farming becomes very necessary which involves keeping them in an enclosure or pen that is very conducive and clean while the farmers provide them with feeds and water that will enhance and promote their growth. Ifediba, (2010) also said that the farmers who are interested in continuous production of snails must be adequately knowledgeable about snail nutrition. The cost of livestock feed ingredients in Nigeria and other parts of the world and their availability have been on the increase and this has hindered production of livestock greatly (Odo, Marie and Nnam, 2014). This situation has led to much interest in the research for alternative sources of feed ingredients of which poultry droppings is one of the alternative sources of feed ingredients that have been sourced for by researchers. Animal protein intake of Nigerians has also been reported to be low which is a major cause of malnutrition amongst Nigerians. The low intake of protein is attributed to the fact that protein is being consumed by both humans and animals, a situation that has led to increase in the demand for animal protein globally, making its sources to be very expensive to purchase. To meet up with the high demand for animal protein especially in Nigeria, it became important for livestock farmers to domesticate animals whose feed can easily be formulated using some local and readily available ingredients, hence the need for snail farming.

Snail farming is a cheap livestock production and simple to operate. If farmers must successfully carry out snail farming all year round, it will depend on the availability of quality feed and its acceptability by the snails. One of the major problems faced by livestock farmers, even snail farmers is feed availability. Snails feed on leaves, fruits, vegetables, tubers, household wastes, amongst others. They also feed on conventional feedstuff which is purchased from the manufacturers and most ingredients used in formulating the conventional feed such as maize, sorghum, soyabeans, and others are quite expensive and also are being used as food by humans. Plant materials used for feeding snails are seasonal and very expensive during the dry season which is their off season.

However, one of the major problems faced by snail farmers is how to get balanced diet for snails all year round which is as a result of high cost of the feed ingredients and unavailability of the plant materials during dry season, and if this problem is not solved, will hinder farmers from producing snails all year round, and the few snails available will be so expensive. In order to solve this problem successfully, the researchers decided to try-out alternative feed ingredient that can be locally sourced for and readily available. It therefore became necessary to study the growth performance of snails to feeds containing poultry droppings as no investigation has been carried out on replacing palm kernel cake with poultry droppings.

The purpose of the study was determined by the Growth Performance of African Giant Land Snails (Archachatinamarginata) to Graded Levels of Poultry Droppings as a Replacement for Palm Kernel Cake in the Diet. Specifically, the study sought to determine:

- Increase in length of African giant land snails fed graded levels of sun-dried poultry droppings.

- Increase in the circumference of growing snails fed graded levels of poultry droppings

- Weight gain of growing snails fed graded levels of poultry droppings.

\subsection{Research Questions}

The following research questions guided the study:

- What is the increase in length of African giant land snails fed graded levels of poultry droppings?

- What is the increase in circumference of African giant land snails fed graded levels of poultry droppings?

- What is the weight gain of snails fed graded levels of poultry droppings?

\subsection{Hypotheses}

The following hypotheses were formulated and tested at probability of 0.05 level of significance:

- There is no significant difference in the mean length of African giant land snails fed graded levels of poultry droppings and those fed palm kernel cake.

- There is no significant difference in the mean circumference of African giant land snails fed graded levels of poultry droppings and those fed palm kernel cake.

- The mean weight gain of growing snails fed graded levels of poultry droppings does not differ significantly with those fed with palm kernel cake. 


\subsection{Experimental Procedure}

A true experimental research design was adopted for this study. Omorogiuwa (2006) described true experimental research design as a design that measures the effect of one variable on another variable. This design was considered most appropriate and adopted for this study because it measured the effect of the independent variable (feed) on the dependent variables. It measured the impact of feed on the growth performance of snails. Three research questions were answered and three hypotheses were tested at 0.05 level of significance. The study was carried out at Ugbowo, in Benin City, Edo State, Nigeria. Benin City is a humid tropical urban settlement which comprises of three Local Government Areas namely IkpobaOkha, Oredo and Egor. It is the biggest City in Edo State with a population of 1,086,882 (Census, 2006). It is located within latitudes $6^{0} 20^{1} \mathrm{~N}$ and $6^{0} 58^{1} \mathrm{~N}$ and longitudes $5^{0} 35^{1} \mathrm{E}$ and $5^{04} 1^{1} \mathrm{E}$ (Okhakhu, 2010).The population for this study was made up of three hundred African giant land snails (Archachatinamarginata) which were purchased from snail dealers at Ugbogui Market near Okada Town in Ovia North East Local Government Area of Edo State and were certified by experts from the departments of Animal Science, University of Benin, Benin City. The snails were allowed to acclimatize for fourteen days during which they were fed pawpaw leaves, fruits, and formulated feeds before the experiment commenced. The sample size for the study was ninety snails. Purposive and random sampling techniques were used to obtain the sample. The ninety snails were selected from the population based on their suitability for the study in terms of health after they were certified by experts. The 90 snails were distributed to 15 pens; each group has three pens as a result of the replicates. Six snails were distributed to each of the 15 pens.

The materials used to formulate the diets include: Maize, Soya bean meal, fish meal and poultry droppings, Bone meal, Vitamin and Mineral Premixes, Fish meal, and Palm kernel cake. Other materials for the experiment included measuring tape, digital weighing balance, feeders and drinkers. The poultry droppings were collected from a poultry farm in Benin City between the hours of 7:00pm and 9:00am. The researchers visited the poultry house to ask for the droppings. The poultry droppings were sun-dried after collection on a clean aluminum tray to a considerable moisture content. Foreign objects were removed from the poultry droppings by hand to avoid contamination of the feed ingredient and reduction in crude protein. The sun-drying was carried out for seven days after which the poultry droppings was milled and stored in a cool dry place before using it to formulate feed at various percentages.

Other feed ingredients (maize, soya bean meal, fish meal, palm kernel cake and additives) were purchased from Third Market in Benin City and milled at a feed mill in the same market. The feed samples were taken to the laboratory at the University of Benin for proximate analysis according to Association of Official Analytical Chemists (AOAC), (1995). The experimental diets were formulated at $0 \%, 25 \%, 50 \%, 75 \%$ and $100 \%$ replacement of palm kernel cake with poultry droppings respectively.

Fifteen pens were constructed and used for the experiment. The pens were washed thoroughly and disinfected a week prior to the assignment of the snails into the pens. The floor of the pens was covered with loamy soil to about $6 \mathrm{~cm}$ high from the bottom. The soil was heated with fire to kill germs and ants before it was introduced into the pens. The feeders and drinkers were also washed thoroughly. The snails were trial-fed 14 days prior to the commencement of the experiment for physiological adjustment. Before the commencement of the experiment, the snails were weighed using a sensitive digital weighing balance and subsequently on a weekly basis. The ninety snails were randomly assigned to five treatment groups with three replicates each in a completely randomized design. Water was provided for the snails in the pen and each treatment group was fed with a particular diet daily for 3 months which is ninety days. Length, circumference and weight gain of the snails were the parameters measured while the experiment lasted. The length and circumference of the snails were determined using measuring tape on weekly basis while the weight gain was determined weekly using digital weighing balance.The feeders and drinkers were emptied and washed daily before using them to serve fresh feed and water. Their faeces were scooped from the floor of the pens to prevent microbial infestation. Water was also sprinkled on the floor of the snail pens weekly to keep and maintain appropriate humidity and temperature needed for snail growth and optimal performance. The soil in the pens was changed monthly to prevent any pathogenic and disease attacks on the snails.

The research questions were answered using mean for the increase in length, circumference and weight gain of the snails. Data collected was subjected to One-Way Analysis of Variance (ANOVA) for testing hypotheses at 0.5 level of significance using Statistical Package for Social Sciences (SPSS). The decision rule was: if 'P' is less than or equal to 0.05, it is significant, therefore the null hypothesis is rejected but if ' $\mathrm{P}$ ' is greater than or equal to 0.05 , it is not significant and the null hypothesis is accepted. The Duncan's New Multiple Range Test was used to separate the difference between the treatment means.

\section{Results}

\subsection{Research Question 1}

What is the increase in length of African giant land snails fed graded levels of poultry droppings? 


\begin{tabular}{|c|c|c|c|c|c|c|}
\hline Treatment & Mean & $\begin{array}{c}\text { Std. } \\
\text { Dev. }\end{array}$ & $\begin{array}{c}\text { Std. } \\
\text { Error }\end{array}$ & Df & F-cal & Sig. \\
\hline & '(g) & & Mean & & & \\
\hline Diet 1 (0\%) & 186.56 & 14.45 & & & & \\
\hline Diet 2 (25\%) & 202.79 & 25.53 & & & & \\
\hline Diet 3 (50\%) & 203.01 & 23.77 & 2.32 & 89 & 2.62 & 0.04 \\
\hline Diet 4 (75\%) & 199.11 & 25.84 & & & & \\
\hline Diet 5 (100\%) & 187.69 & 12.95 & & & & \\
\hline
\end{tabular}

Table 1: The Increase in Length of Snails Fed Graded Levels of Poultry Droppings

Key: Std. Dev. = Standard Deviation, $D f=$ Degree Of Freedom, F-Cal = F-Calculated

The result in Table 1 indicated the differences in the increase of the mean length of the different treatments. Snails in treatment with diet 3 which contained 50\% poultry droppings had the highest mean length of 203.01 which was followed closely by those in treatment with diet 2 containing $25 \%$ poultry droppings with mean length of 202.79 . Snails in treatments with diet 4, diet 5 and diet 1 had mean length of 199.11, 187.69 and 186.56 respectively, indicating that those at $75 \%, 100 \%$ and $0 \%$ levels of replacement did not perform better.

\subsubsection{Hypothesis 1}

There is no significant difference in the mean length of African giant land snails fed graded levels of poultry droppings and those fed palm kernel cake.

\begin{tabular}{|c|c|c|c|c|c|c|c|}
\hline & Sum of & Df & Mean & & F & Sig. & Decision \\
\hline & Square & & Square & & & & \\
\hline Between Groups & 4733.103 & 4 & 1183.276 & & & & \\
\hline Within Groups & 38438.61 & 85 & 452.219 & 2.617 & 0.041 & Rejected & \\
\hline Total & & 43171.72 & 89 & & & & \\
\hline
\end{tabular}

Table 2: Analysis of Variance (ANOVA) of the Mean of Increase in Length of Snails Fed Graded Levels of Poultry Droppings

Table 2 showed that there was a significant difference in the total increase in length of the snails as the $\mathrm{f}$ calculated is 2.62 with a p-value at 0.04 which is less than 0.05 . Therefore, the null hypothesis was rejected.

\begin{tabular}{|c|c|c|c|}
\hline Group & $\mathbf{N}$ & \multicolumn{2}{|c|}{ Subset for alpha = 0.05 } \\
\hline Diet 1 & 18 & $186.56^{\mathrm{a}}$ & $\mathbf{2}$ \\
\hline Diet 2 & 18 & & $202.9^{\mathrm{b}}$ \\
\hline Diet 3 & 18 & & $203.01^{\mathrm{b}}$ \\
\hline Diet4 & 18 & $199.11^{\mathrm{a}}$ & $199.11^{\mathrm{b}}$ \\
\hline Diet 5 & 18 & $187.69^{\mathrm{a}}$ & \\
\hline
\end{tabular}

Table 3: Duncan's Post Hoc Test for Increase in Length of Snails Fed Graded Levels of Poultry Droppings

From Table 3, the mean values of diets 1, 4, and 5 showed no significant difference; thus, carrying the superscripts (a). Also, diets 2, 3, and 4 showed no significant difference in the mean values of increase in length. Meanwhile, diets (1 \& 2) and diet ( $3 \& 5$ ) showed a significant difference as they carried superscripts (a) and (b).

\subsection{Research Question 2}

What is the increase in circumference of African giant land snails fed graded levels of poultry droppings? Data for answering research question two is presented in Table 4.

\begin{tabular}{|c|c|c|c|c|c|c|}
\hline Treatment & Mean & Std. Dev. & Std. Error & Df & F-cal & Sig. \\
\hline & (g) & & Mean & & & \\
\hline Diet 1 (0\%) & 289.09 & 20.15 & & & & \\
\hline Diet 2 (25\%) & 310.51 & 31.87 & & & & \\
\hline Diet 3 (50\%) & 289.7 & 16.62 & 2.62 & 89 & 2.41 & 0.06 \\
\hline Diet 4 (75\%) & 298.54 & 26.2 & & & & \\
\hline Diet 5 (100\%) & 293.23 & 22.93 & & & & \\
\hline
\end{tabular}

Table 4: The Increase in Circumference of Snails Fed Graded Levels of Poultry Droppings

Key: Std. Dev. = Standard Deviation, Df= Degree Of Freedom, F-Cal = F-Calculated, NS = Not Significant 
The result showed in Table 4 indicated slight differences in the increase of the mean circumference values of various treatments with treatment with diet 2 having the highest increase with mean value of 310.51 . This was followed by snails in treatments with diet 4 and diet 5 with mean values of 298.54 and 293.23 respectively. Snails in treatment with diet 3 showed mean value of 289.70 while those in treatment with diet 1 which is the control group indicated a mean value of 289.09 .

\subsubsection{Hypothesis 2}

There is no significant difference in the mean circumference of African giant land snails fed graded levels of poultry droppings and those fed palm kernel cake.

\begin{tabular}{|c|c|c|c|c|c|c|}
\hline & Sum of & Df & Mean & F & Sig. & Decision \\
\hline & Square & & Square & & & \\
\hline Between Groups & 5613.173 & 4 & 1403.293 & & & \\
\hline Within Groups & 49474.32 & 85 & 582.051 & 2.411 & 0.055 & Accept \\
\hline Total & 55087.49 & 89 & & & & \\
\hline
\end{tabular}

Table 5: Analysis of Variance (ANOVA) of the Mean of Increase in Circumference of Snails Fed Graded Levels of Poultry Droppings

Using the result shown in Table 5, no significant difference occurred between groups of experimental snails. It showed that there is no significant difference in the total increase in circumference of the experimental snails among the treatments. The total increase in circumference of snails in the treatments were similar. The f-calculated is 2.411 at 4 and 85 degree of freedom, with a p-value at .055 which is greater than the alpha level of .05. This mean that there is no significant difference in the mean scores of the circumference of African giant land snails fed graded levels of poultry droppings and those fed palm kernel cake. Therefore, the null hypothesis was accepted.

\subsection{Research Question 3}

What is the weight gain of growing snails fed graded levels of poultry droppings?

Data for answering research question three is presented in Table 6.

\begin{tabular}{|c|c|c|c|c|c|c|}
\hline Treatment & Mean & Std. Dev. & Std. Error & Df & F-cal & Sig. \\
\hline & & $\mathbf{( g )}$ & Mean & & & \\
\hline Diet 1 (0\%) & 2.16 & 0.44 & & & & \\
\hline Diet 2 (25\%) & 2.18 & 0.46 & & & & \\
\hline Diet 3 (50\%) & 2.4 & 0.53 & 0.05 & 89 & 0.75 & 0.56 \\
\hline Diet 4 (75\%) & 2.3 & 0.5 & & & & \\
\hline Diet 5 (100\%) & 2.25 & 0.42 & & & & \\
\hline
\end{tabular}

Table 6: The Weight Gain of Snails Fed Graded Levels of Poultry Droppings

Key: Std. Dev. = Standard Deviation, $D f=$ Degree of Freedom, F-Cal = F-Calculated

The performance of snails on weight gain as presented in Table 6 showed that snails in treatment with diet 3 which contained $50 \%$ poultry droppings performed better than others as it has the highest mean weight gain of 2.40 . This was followed by the snails in treatment with diet 4 which contained $75 \%$ poultry droppings with a mean value of 2.30 . Snails in treatments with diet 5 , diet 2 and diet 1 showed the mean value of $2.25,2.18$ and 2.16 respectively.

\subsubsection{Hypothesis 3}

The mean weight gain of growing snails fed graded levels of poultry droppings does not differ significantly with those fed with palm kernel cake.

\begin{tabular}{|c|c|c|c|c|c|c|}
\hline & Sum of & Df & Mean & F & Sig. & Decision \\
\hline & & & Square & & Square & \\
\hline Between Groups & 0.662 & 4 & 0.166 & & & \\
\hline Within Groups & 18.867 & 85 & 0.222 & 0.746 & 0.063 & Accept \\
\hline Total & & 19.53 & & 89 & & \\
\hline
\end{tabular}

Table 7: Analysis of Variance (ANOVA) of the Mean of Weight Gain of Snails Fed Graded Levels of Poultry Droppings

Using the result shown in Table 7, no significant difference occurred between groups of experimental snails. It showed that there is no significant difference in the total weight gain of the experimental snails among the treatments. The total weight gain of snails in the treatments were similar. The f-calculated is .746 at 4 and 85 degree of freedom, with a pvalue at .063 which is greater than the alpha level of .05. This mean that there is no significant difference in the mean 
scores of weight gain of African giant land snails fed graded levels of poultry droppings and those fed palm kernel cake. Therefore, the null hypothesis was accepted.

\section{Discussion of Findings}

The findings of the study have been organized and discussed based on the research questions and hypotheses that guided the study. The result as shown in Table 1 revealed that the highest increase in the mean length of snails are the snails in treatment with diet 3 containing 50\% poultry droppings (203.01). Comparing the result with those in treatments with diets 1, 2, 4 and 5 showed that the snails in treatment with diet 3 performed better. The data analyzed in Table 1 showed that there is a significant difference that occurred in the mean length of snails fed graded levels of poultry droppings and those fed palm kernel cake. This is in agreement with the assertion of Akankali and Nwafili (2015) who reported that dried poultry manure can be used as substitute complementary fish meal to replace soyabean meal in the diets.

The result of this study in table 4 showed that snails in treatment with diet 2 containing $25 \%$ poultry droppings had the highest mean circumference. Comparing the result to those in other treatments showed that snails in treatment with diet 2 performed better than others in terms of increase in the circumference of the snails. The Table 5 showed that there is no significant difference in the mean circumference of snails fed graded levels of poultry droppings and those fed palm kernel cake. This corroborated the report of Ademolu and Idowu (2005) that poultry droppings contributed to higher shell circumference gain.

The use of poultry droppings as a replacement for palm kernel cake in the diet for snails showed no significant difference in the weight gain of the experimental snails. The highest weight gain with mean of 2.40 shown by snails in treatment with diet 3 containing 50\% poultry droppings in table 6 indicated the suitability of diet 4 to other diets. This further showed that incorporating poultry droppings up to about $50 \%$ in the diets for snails will have no growth effect on the snails negatively; rather it will help to reduce the cost of feed ingredients. This result showed that poultry droppings is useful as it can be used to replace palm kernel cake in the diets for snails. The weight gain of snails fed with poultry droppings as shown in Table 7 revealed that no significant difference occurred between the groups of snails fed graded levels of poultry droppings. This indicated that poultry droppings are useful and acceptable in compounding feeds for snails for better weight gain. This corroborated the report of Odo et al (2014) that poultry waste is suitable to replace wheat offal and palm kernel cake for better weight gain in snail production.

\section{Conclusion and Future Scope}

The following conclusions were made by the researchers based on the findings of the study:

Poultry droppings could be fed to snails at $50 \%$ and $75 \%$ levels of supplementation. This helps to minimize cost of production of snails. The study showed that snails could be fed $50 \%$ and $75 \%$ poultry droppings for better increment in length, circumference and weight gain. Generally, snails fed graded levels of poultry droppings performed better than those in the control group. The performance could be traceable to higher protein content of poultry droppings due to the mixture of poultry feeds in the droppings.

From the experiment, it could be inferred that poultry droppings could be used to replace palm kernel cake in snail diets to ensure that snails are available all year round. The result from the study showed that poultry droppings have nutritive value which makes it useful as a feed ingredient for snails. The trial also proved that replacing palm kernel cake with poultry droppings in snail diet will both increase productivity of snail farmers and as well reduce overall cost of snail production.

Researchers should carry out further researches on the use of poultry droppings as replacement for other protein sources such as soya bean in the diet of African Land Giant snails.

\section{Recommendations}

The following recommendations were made from the findings of this study:

- The use of poultry droppings at 50\% and $75 \%$ levels as a replacement for palm kernel cake in snail diet is highly recommended.

- Workshops and seminars should be organized by the Ministry of Agriculture for snail farmers and the general public using extension agents for dissemination of information as regarding the use of poultry droppings as a feed ingredient for snails.

- Government should take more interest in snail farming by encouraging job seekers and snail farmers through financial and technical support.

- Government and Non-Government Organizations should assist researchers on snail farming financially to carry out more researches on snail farming and to publish their findings for wider publicity.

\section{References}

i. Ademolu, K.O. \&Idowu, A.B.(2005). The use of poultry droppings as snail feed.Journal of Animal and Veterinary Advances, vol. 4, No 6, pp. 566-569.

ii. Akankali, S. A. \&Nwafili, S. A. (2015). Management of organic waste impacts on the environment: Utilization as fish feed,'International Journal of Development and Sustainability, vol. 4, No 5, pp. 513-528.

iii. AOAC, (1995). Official Methods of Analysis. Association of Official Analytical Chemists, WashingtonD.C.,15th Ed.

iv. Cobbinah, R. C. (2008).Practical Guide on Snail Farming in West Africa.Technical Centre for Agricultural and Rural Cooperation. 
v. Ifediba, C. (2010). The effect of feeding varying levels of rumen digesta on the growth of African land giant snail (Archachatinamarginata). Unpublished M.Ed Thesis of Department of Vocational and Technical Education, University of Nigeria, Nsukka.

vi. Odo, B. I., Marire, B. N.\&Nnam, O. C. (2014). Replacement value of poultry waste for wheat offal and palmkernel cake (P.K.C.) in broiler diet.International Journal of Applied Science and Technology, vol. 4 No 3, pp. $255-258$.

vii. Okereke-Ejiogu, E. N., Ogueri, E. I. \&Umunakwe, P. C. (2016). Adoption of snail production technologies byfarmers in Owerri West Local Government Area of Imo State, Nigeria.Futo Journal Series (FUTOJNLS).Vol. 2 No 1, pp. 62-69.

viii. Okonta, B. O. (2012). Performance of giant African land giant snail Archachatinamarginata(Swainson) fed withselected diets.Global Journal of Bio-Science \&Biotechnology, vol. 1 No 2, pp. 182-185.

ix. Okhakhu, P. A. (2010). The significance of climatic elements in planning the urban environment of Benin City, Nigeria. Unpublished PhD Thesis. Ekpoma-Nigeria: Department of Geography and Regional Planning, Ambrose Alli University.

x. Omorogiuwa, K. O. (2006). Research and applied statistics for the behavioural sciences. Benin City: MindexPublishing Company.

xi. Ugwuowo, L. C. (2009). Effects of different protein sources on the growth performance and carcass characteristics ofAfrican giant land snail (Archachatinamarginata),'Unpublished M.ScThesis of Department of Animal Science, University of Nigeria, Nsukka. 